Historic, Archive Document

Do not assume content reflects current scientific knowledge, policies, or practices. 



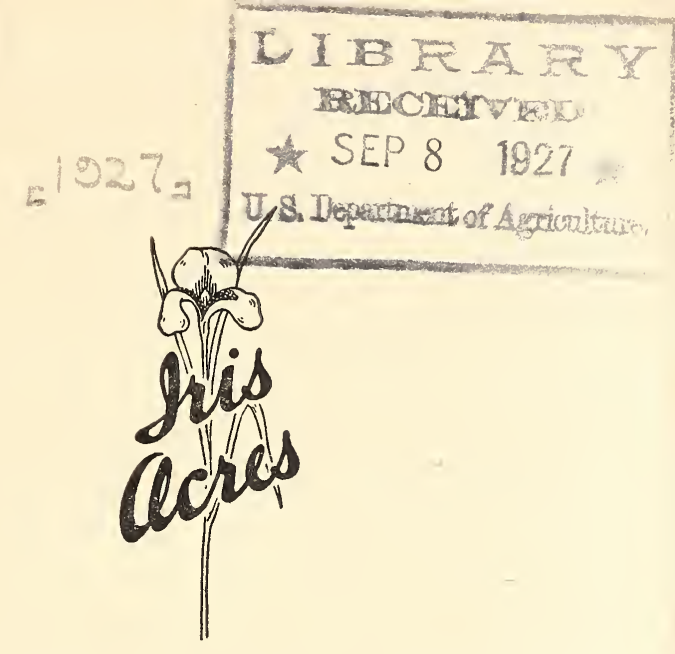

Jlardy follants

For Mock Garden and Sorder

UNIFORM PRICE, unless otherwise noted, is $15 \mathrm{c}$ per plant; six of one variety for $75 \mathrm{c}$; dozen for $\$ 1.50$. We pay postage on all orders amounting to $\$ 1$ and over and guarantee arrival of plants at your postoffice in good condition.

\section{IRIS ACRES}

MOLALLA -:- OREGON 
ACHILlEA, The Pearl. 2-3 ft. A profusion of double, white, button-like flowers on good cutting stems all summer. Somewhat weedy in growth. Dry sun.

ACHILLEA roseum (Rosy Milfoil). $2 \mathrm{ft}$. Feathery foliage and flat heads of rose-red flowers, passing to old-rose, a very pleasing shade. Attractive and withstands drouth.

AGROSTEMMA coronaria (Mullein Pink). $2 \frac{1}{2}-3 \mathrm{ft}$. The silvery foliage contrasts with flowers of showiest crimson in June-July. Erect growth. Sun.

AMARYLLIS belladonna (Beladonna Lily). 2-3 ft. Luxuriant foliage in earliest spring, dying down to be followed in late August by large umbels of lovely pink, lily-like blooms at tops of stalks which shoot up quickly after the first fall rains. Hardy in this climate but in the east grown as a pot plant. Immense bulbs, $50 \mathrm{c}$; large, $40 \mathrm{c}$; fair sized, $30 \mathrm{c}$ each.

ANEMONE japonica (Japanese Windflower). 2-3 ft. Graceful plant with a beauty of blossom and foliage which makes them unequalled for garden display and cut flowers all through the fall. Give part shade and do not disturb often.

QUEEN CHARLOTTE. Semi-double flowers of silvery pink. Each $30 \mathrm{c}$.

WHIRLWIND. Pure white flowers of heavy texture. Yellow centers. Each $30 \mathrm{c}$.

ARTEMISIA lactiflora. $3-5 \mathrm{ft}$. Foliage ornamental all season. Long panicles of creamy-white, fragrant bloom from July to frost. A graceful cut flower. Especially good as a tall, informal hedge or against high walls. Large plants $25 \mathrm{c}$; doz. $\$ 2.50$.

ASTER (Michaelmas Daisy). 3-5 ft. Narrow green foliage and thousands of starry flowers in fall, giving the effect of a cloud of soft color. Use in masses in border and for backgrounds.

BEAUTY OF COLWALL. Semi-double flowers of ageratum-blue.

LAEVIS. Sky blue.

NEW ENGLAND. Violet-purple. A native of the eastern state, improving wonderfully under cultivation.

AUBRIETIA. 4-8 in. Dainty, creeping evergreen plant for edgings and rockery. Thrive in poor soil, through cold and drouth. Planted in rock crevice will form cascade of color. Foliage, silver and green; flowers rose-lilac.

BELLIS, perenne (English Daisies). 3-6 in. Gay ground cover for cool situations in part or whole shade. Bloom from late winter through spring. Ked, white, pink. Doz. $75 \mathrm{c}$.

BOCCONIA (Plume Poppy). 6-8 ft. Immense leaves of distinctive shape. Terminal panicles of cream colored flowers, July-August. Make striking clump for tall border or for the center of a bed. Effect of tropical plant. Each $30 \mathrm{c} ; 2$ for $50 \mathrm{c}$.

BALM. I ft. An old fashioned pot herb of delightful fragrance. Foliage good all summer.

BOLTONIA asteroides. 4-6 ft. Aster-like plants but of sturdier growth and broader foliage. Myriads of white, yellow centered flowers all fall. Buds are pink.

CAMPANULA. 18-24 in. Slender stalks with pointed leaves and bells of good size and of a clear blue, up and down stalk. Forms good clumps. Sun or part shade. 
CARNATION, Hardy White. Border plant of delicious fragrance. Good cut flower. $1 \mathrm{ft}$.

CERASTIUM (Snow-in-Summer). 6-8 in. Low-growing border plant with silvery foliage, and white flowers in spring. Excellent for sunny rock garden.

CHINESE LANTERN PLANT. 1-2 ft. Forms dense bushes with inconspicuous flowers, followed by showy, lanternlike, orange-red fruits. These are often dried for winter decorations. Each 25c; five for \$1.00.

CHRYSANTHEMUM. Hardy garden varieties, that require no coddling.

BRONZE BUTTON. Small, double blooms of bronzyred. Popular for cutting.

GARNET BUTTON. A deep, rich red.

PINK DAISY. Semi-double, yellow centered. Like big daisies. Early.

WHITE BALL. Opens rich cream, passing to pure white. Full double.

ROSE. Large, fluffy blooms of rich rose passing to oldrose.

RED BEAUTY. Rich red. Larger than the button varieties, but small. Double.

LADY ASTOR. Large garnet. Free flowering.

BRONZE BEAUTY. Early and free.

YELLOWBELL. Bright, clear yellow.

PINK BEÁUTY. Rose pink. Large, fluffy blooms.

DELPHINIUM. 4-8 ft. These thrifty, year-old, field-grown plants are grown from the best seed obtainable and should give many lovely shades in this popular flower. Very easily grown from this size plants. Should bloom this year. Each $20 \mathrm{c} ; 3$ for $50 \mathrm{c} ; 7$ for $\$ 1.00$.

DIANTHUS. Hardy Garden Pink. Masses of flat, blue-green foliage and a profusion of pink blossoms with darker eye. Good for edging walks or for rockery. Dozen $75 \mathrm{c}$.

DIANTHUS barbatus (Sweet William). 18-24 in. It is hard to find a flower to take the place of the Sweet William for mass of bloom and richness of colors. A biennal, but sows itself freely. Doz. $\$ 1.00$, straight or assorted.

NEWPORT PINK. Watermelon pink. A very popular color.

REDS in several shades including very dark, dark, bright, and light.

PINKS. Dark and light.

WHITE.

VARIEGATED.

DORONICUM. 18-24 in. Large, yellow, daisy-like flowers on long cutting stems. They are especially vaiued because they bloom very early in the spring. Each $20 \mathrm{c}$; 3 for $50 \mathrm{c}$.

FEVERFEW. 18-24 in. Is loaded with its small, double, cream-white blooms all summer. Useful for cutting. Feathery foliage.

FOXGLOVE. 3-6 ft. Stately and picturesque. Plant in masses, preferably in light shade. Colors are white and rose but we cannot guarantee color of flowers. Each 20 c; 3 for $50 c$. 
GYPSOPHILA (Baby's Breath). 2-3 ft. Plant this wherever a mass of delicate, misty bloom is needed to fill a bare place or soften bright colors. Indispensable for bouquets.

HELENIUM. $4 \mathrm{ft}$. A fall-blooming plant for the rear of the border. Forms good clumps and produces its flowers very freely.

RIVERTON BEAUTY. Lemon-yellow with black center.

RIVERTON GEM. Old-gold, suffused terra-cotta, passing to wall-flower red.

HELIANTHUS (Hardy Sunflower). 4-6 ft. Brings broad masses of gold to the late fall garden, blooming freely from October to frost.

GLORY OF AUTUMN. Graceful sprays of golden-yellow flowers on good cutting stems.

HEMEROCALLIS Fulva (Tawny Day Lily). $3 \mathrm{ft}$. Corn-like leaves and lily-like flowers of coppery orange, shaded crimson in July. Graceful and effective. Prefer partial shade and are especially luxuriant on moist banks. Each $20 c ; 3$ for $50 c$.

HOLLYHOCK. (5-13 ft.). When an artist wishes to make a pictured house look home-like and picturesque he adds a few hollyhocks. Gardeners may well follow the artist's example. The single varieties are more hardy as well as more graceful and artistic than the double. Once planted in rich soil with sunny exposure they will look after themselves. Colors cross and cannot be guaranteed in seedlings. Our collection includes a bewildering range of shades in single and semi-double, some of them fig-leaved. Small plants, $15 \mathrm{c} ; \$ 1.50$ per doz.; larger $20 \mathrm{c} ; \$ 2.00$ per doz.

LAVENDER. 18-in. Forms large rounded clumps of gray foliage which make an excellent foil for flowers such as pink snap dragons or pentstemons. Topped in July by its many spikes of fragrant lavender flowers, which may be dried for scenting linen.

LINUM perenne (Flowering Flax). 18-24 in. Wiry, graceful stems and airy foliage. The flowers open by myriads in the sunshine, forming a cloud of delicate blue.

LUPINE polyphyllus. 3-4 ft. These hardy lupines are evergreen in mild winters such as we often have on the west coast, and form large shrubby bushes as wide as they are tall. Make an excellent hedge and should be allowed plenty of room or they crowd out and shade smaller plants. The foliage is finer cut than in the native lupine and makes a good background to set off the colors of other flowers. Flowers are in ft. long spikes, white and yellow and sweetly fragrant. We will have other colors to offer in the fall. Small plants. $15 \mathrm{c} ; 6$ for $75 \mathrm{c}$; larger $20 \mathrm{c} ; 3$ for $50 \mathrm{c}$.

MONARDA didyma (Bergamot or Scarlet Bee Balm). 2-3 ft. Aromatic foliage and brilliant flowers of Cambridgescarlet, bergamot-shaped. Will thrive in sun or shade and gives the deepest note of red in mid-summer garden. Give a dark background for full effect.

OENOTHERA (Evening Primrose). $2-3 \mathrm{ft}$. Stout plants of somewhat coarse apperance. The big, pale yellow, saucer-shaped flowers open as the sun sets. With their fragrance and pale beauty they add witchery to moon-lit nights.

PENTSTEMON. $2 \mathrm{ft}$. Showy flowers of easiest culture. We offer this spring only a handsome blue variety which resembles the scarlet Barbatus in growth but is more floriferous. Prefers a loose, sandy soil. Blooms all summer if watered. Each $20 \mathrm{c} ; 3$ for $50 \mathrm{c}$. 

PHLOX, Perennial. 2-3 ft. They give a wealth of midsummer bloom if given a cool situation with moisture, but will not do well in hot sun without irrigation.

WILDWOOD. Tall growing and free-flowering. Bright pink with darker eye. Each 25c; 5 for $\$ 1.00$.

UN-NAMED MIXED COLORS. Each $20 \mathrm{c} ; 6$ for $\$ 1.00$.

PHYSOSTEGIA virginica. 2-3 ft. Long spikes of tubular flowers in delicate pink, giving effect of a gigantic heather. Forms large clumps. Prefers moist soil.

POLYANTHUS (Primrose). 6-12 in. Hardy little plants of easiest culture which make a harmony of blended colors in earliest spring and until hot weather. Prefers a cool situation in partial shade. Red, yellow, orange and blends.

SPECIAL. A lovely double lavender. Each 25c; 5 for $\$ 1.00$.

PYRETHRUM roseum (Persian or Painted Daisy). 18-24 in. Rose-pink, daisy-like flowers of special value for cutting. May to July.

RANUNCULUS (Double Buttercup). 6 in. A hardy creeper with glossy foliage and gold buttons of flowers, also with a gloss. Showy and a rampant grower.

RUDBECKIA (Golden Glow). $6 \mathrm{ft}$. Large, double yellow flowers on long stems.

SALVIA azurea (Blue Sage). $3-4 \mathrm{ft}$. A relative of the popular Scarlet Sage but perfectly hardy and with flowers of a dainty sky-blue on slender, drooping stems. Very desirable. August-September.

SANTOLINA (Ground Cypress). I ft. Forms perfect circles of silvery-gray foliage which always attracts attention in the garden and contrasts well with other plants. May also be kept trimmed to form a neat border. lts own yellow button flowers are not particularly attractive and may well be kept trimmed away.

SCABIOSA (Pin-Cushion Flower). 2-3 ft. Handsome flowers which will bloom happily through the driest summer. Very popular with florists as a cut flower.

WHITE BONNET. Lovely fluffy blooms of purest white. Can also supply pink and red.

SEDUM sieboldi. Round, succulent foliage and bright pink flowers in August-September. A semi-dwarf variety.

SEDUM spectabile. 18 in. Erect grower with broad foliage and large heads of showy rose-colored flowers in late fall.

SEDUM sempervivum (Houseleek). Also called Hen-andChickens. Quaint rosettes of thick leaves, green, red edged. All sedums are desirable for rock gardens or walls, in dry, sunny situations.

SHASTA DAISY. lndispensable for summer flowering. Try large clumps of them in the foreground of your delphinium plantings or for edging wide paths.

PERFECTION. A variety with long petals and small yellow centers. $2 \frac{1}{2} \mathrm{ft}$.

ALASKA. Burbank's improved. Broad foliage of great substance and very large flowers. $2 \frac{1}{2}-3 \mathrm{ft}$. Each 20 c; 5 for $\$ 1.00$.

STACHYS lanata (Rabbit's Ear). 12 in. Thick, white, plushlike leaves and small purple flowers in dense whorls. For sunny rock garden and border. 
THYME serpyllum (Creeping Thyme). 6 in. Forms dense mats of dense green, finely cut foliage with clouds of mauve flowers. On hot dry banks where grass is difficult to establish it will furnish a close, fragrant carpet. Excellent for sunny rock gardens. The aromatic foliage is used for seasoning.

VINCA major (Periwinkle). $1 \mathrm{ft}$. Evergreen trailer well adapted for covering shady banks. It resists drouth and if kept cut back will soon spread and cover the ground, even under trees. The pretty flowers are of a flat blue and of fair size.

VIOLA, Geo. Wermig (Tufted Pansy). 9-10 in. There is scarcely a better edging plant to be had. It spreads rapidly by clumps and if watered and the blooms sheared occasionally, will bloom the season through. They are rather more like violets than pansies, of a rich violet-blue. Bourne in great profusion on good cutting stems.

WALLFLOWER. The early flowering, low-growing Phoenix and Vulcan varieties grown from seeds direct from Sutton of England. Rich chestnut brown and blood red. Fra. grant. Year old plants. Each 25c; five for $\$ 1.00$.

YUCCA filamentosa (Adam's Needle). 4-6 ft. Broad, swordlike leaves and tall, branching spikes of drooping, creamy. white flowers. Bold and handsome plants for rock gar. den or lawn. Will thrive on dry banks. The flowers take on a new beauty by moonlight. Well established plants, each $30 \mathrm{c}$.

\section{IRIS ACRES}


